\title{
AMBIENT LEVELS AND DRY DEPOSITION FLUXES OF MERCURY TO LAKES HURON, ERIE AND St. CLAIR
}

\author{
N. PIRRONE, G. GLINSORN and G.J. KEELER \\ Air Quality Laboratory, The University of Michigan, Ann Arbor, MI 48109-2029
}

\begin{abstract}
Ambient concentrations and dry deposition fluxes of $\mathrm{Hg}$ in the gas and particle phase to Lakes St. Clair, Erie and Huron were estimated with a hybrid receptor-deposition model (HRD). The ambient gas and particulate phase $\mathrm{Hg}$ concentrations were predicted to vary by a factor of 12 to 18 during the transport of air masses traversing the lakes. The ensemble average deposition fluxes of fine particle $\mathrm{Hg}$ ranged from $7 \mathrm{pg} / \mathrm{m}^{2}$-h to $15.3 \mathrm{pg} / \mathrm{m}^{2} \mathrm{~h}$ over Lake St. Clair, 0.5 to $4.2 \mathrm{pg} / \mathrm{m}^{2}$-h over Lake Huron and 5.1 to $20.6 \mathrm{pg} / \mathrm{m}^{2}-\mathrm{h}$ over Lake Erie. The deposition flux of coarse particle $\mathrm{Hg}$ was in the range of 50 to $84 \mathrm{pg} / \mathrm{m}^{2}-\mathrm{h}$ over Lake St. Clair, 4.7 to $24.2 \mathrm{pg} / \mathrm{m}^{2}$-h over Lake Huron and 5.1 to $20.6 \mathrm{pg} / \mathrm{m}^{2}-\mathrm{h}$ over Lake Erie. Gaseous $\mathrm{Hg}$ volatilized at a rate of 0.21 to $0.52 \mathrm{ng} / \mathrm{m}^{2}$-h from Lake Huron and 0.13 to 0.36 from Lake Erie. Gas phase $\mathrm{Hg}$ was deposited at a rate of $5.9 \mathrm{ng} / \mathrm{m}^{2}-\mathrm{h}$ and/or volatilized at a rate of $0.5 \mathrm{ng} / \mathrm{m}^{2}-\mathrm{h}$ from Lake'St. Clair depending upon the location of the sampling site used in the HRD model. The effect of meteorological conditionš, particle size distributions and type and location of the sampling sites played an important role in the transfer of atmospheric $\mathrm{Hg}$ to and/or from the lakes.
\end{abstract}

\section{Introduction}

Mercury is emitted into the atmosphere from a multitude of natural sources and from previously contaminated natural waters. Emissions from anthropogenic sources including coal and oil combustion, municipal solid waste and sewage sludge incineration, and smelting operations are more significant (EPA, 1993). As a consequence of the increase of anthropogenic emissions in industrialized countries some investigations indicate that ambient $\mathrm{Hg}$ concentrations have increased by $1.5 \%$ per year in the Northern Hemisphere and by $1.2 \%$ per year in the Southern Hemisphere during the 1977-1990 period (Slemer and Langer, 1992). In addition, increases in $\mathrm{Hg}$ deposition rates have been reported for the north temperate lake systems in Wisconsin, Minnesota and Sweden (Slemer and Langer, 1992; Swain et al., 1992; Meger, 1986; Lindqvist et al., 1991; Nater and Grigal, 1992). Swain et al. (1992) reported a $2 \%$ increase in $\mathrm{Hg}$ deposition rates in remote lakes in Wisconsin and Minnesota. Moreover, analysis of lake sediments and dated soils (Rada et al., 1989; Norton et al., 1990) as well as peat bogs (Norton et al., 1990) suggest that $\mathrm{Hg}$ deposition may have doubled during the last century. It is now widely accepted that atmospheric deposition is an important pathway in the transfer of $\mathrm{Hg}$ to natural waters.

This paper presents estimates of deposition fluxes and exchange rates of gas phase $\mathrm{Hg}$ to Lakes St. Clair, Huron and Erie. Ambient concentrations and particle size distributions of atmospheric Hg measured in the Detroit urban/industrial area in April 1992 (Keeler et al., 1994a) and March 1994 are used as input to a hybrid receptor-deposition_model (HRD) to estimate the ambient concentrations, deposition fluxes, and exchange rates of the gas phase $\mathrm{Hg}$ at the air-water interface. The HRD model accounts for temporal and spatial variations in the ambient concentration, deposition flux and gas exchange rate associated with changing meteorological conditions, particle size distributions, and hydrodynamics (i.e., wave frequency and spray formation). 


\section{Methods}

\subsection{SAMPLING SITES}

During a 10-day intensive study in April 1992 (Keeler et al. 1994a), ambient Hg concentrations for both gas and particle phases were measured at two urban sites: Site- 5 was located in downtown Detroit close to Zug Island, which is one of the most industrialized areas in Southeastern Michigan. Anthropogenic $\mathrm{Hg}$ is emitted (in this area) from a large number of emission sources including coke ovens, iron and steel plants, incinerators, power generation facilities, and lime and cement operations (Pirrone et al., 1994). The second site (Site-1) was located in a mixed residential/industrial land use area which is northwest of the Detroit Incinerator (GDRRA), one of the largest municipal solid waste incinerator facilities in the US which has been operating in Detroit since 1989.

In March 1994, an 18-day intensive study was performed in Detroit at the urban site (Site-5) to determine ambient $\mathrm{Hg}$ concentrations in the gas phase as well as the $\mathrm{Hg}$ associated with fine fraction $(<2.5 \mu \mathrm{m})$ and total suspended particulate matter. In addition, a six stage-microorifice cascade impactor (MOI) was used to determine the particle size distribution of particulate $\mathrm{Hg}$ in the atmosphere. The dry deposition velocity of particulate $\mathrm{Hg}$ in each particle size over Lakes Erie, St. Clair and Huron was then calculated.

\subsection{ANALYTICAL PROCEDURES}

Total particulate $\mathrm{Hg}$ was collected using an open-faced Teflon filter pack (Savillex) with a 47 $\mathrm{mm}$ diameter glass fiber filter (Gelman Science Type A/E) for 24 hours at a nominal flow rate of $30 \mathrm{~L} / \mathrm{min}$. Particulate $\mathrm{Hg}$ in the fine fraction $(<2.5 \mu \mathrm{m})$ was collected onto a $47 \mathrm{~mm}$ diameter glass fiber filter (Gelman-Science Type A/E) after removal of particles in the coarse fraction using a Teflon-coated aluminum cyclone (University Research Glassware, N. C.). A six stage-MOI was used to measure the size distribution of the particulate $\mathrm{Hg}$ (Keeler et al., 1994b). Samples were collected onto $37 \mathrm{~mm}$ glass fiber filters at a nominal flow rate of $30 \mathrm{~L} / \mathrm{min}$ for 24 hours. After sampling, the filters were individualy placed in acid-cleaned petri dishes and stored at $-40^{\circ} \mathrm{C}$ until analysis. Gas phase $\mathrm{Hg}$ was collected using gold-coated glass beads at a nominal flow rate of 300 $\mathrm{mL} / \mathrm{min}$ for 12 and 24 hours.

Each glass fiber filter was extracted in $30 \mathrm{~mL}$ of $10 \% \mathrm{HNO}_{3}$, placed in a CEM MDS-2000 microwave oven for 20 minutes at $160{ }^{\circ} \mathrm{C}$, and then allowed to react for 12 hours at room temperature. After digestion, $10 \mathrm{~mL}$ of extract were removed with an Eppendorf pipet and placed into $30 \mathrm{~mL}$ acid cleaned polyethylene bottle for trace metals analysis using an ICP-MS. The remaining extract was used for $\mathrm{Hg}$ analysis after addition of $0.25 \mathrm{~mL}$ of $\mathrm{BrCl}$ to oxidize all the mercury to $\mathrm{Hg}^{++}$. The glass fiber filters from the MOI were extracted with $10 \mathrm{~mL}$ of $10 \% \mathrm{HNO}_{3}$ at $160^{\circ} \mathrm{C}$ for 20 minutes, allowed to react for 12 hours at room temperature, and oxidized to $\mathrm{Hg}^{++}$ with $0.25 \mathrm{~mL}$ of $\mathrm{BrCl}$.

The $\mathrm{Hg}$ analysis was performed using dual amalgamation with Cold Vapor Atomic Fluorescence Spectrometry (Fitzgerald and Gill, 1979). Excess $\mathrm{BrCl}$ was removed by ädding 100 $\mu \mathrm{L}$ of hydroxylamine hydrochloride to $5 \mathrm{~mL}$ aliquots of filter extract and allowed to react for 5 min. Subsequently, $0.5 \mathrm{~mL}$ of stannous chloride were added to reduce the $\mathrm{Hg}^{++}$to $\mathrm{Hg}^{0}$, which was subsequently purged from the solution with an $\mathrm{Hg}$-free nitrogen stream and concentrated onto a gold-coated sand trap. Calibration curves covering the expected concentration-levels were analyzed on a daily basis and the check of standards was performed every six samples. 


\subsection{MODELING}

The atmospheric transport of contaminants and their transfer to natural waters is affected by their chemical transformations and vapor-particle partitioning during transport, meteorological parameters, and wave dynamics and spray formation at the air-water interface. In order to estimate the deposition fluxes of particulate and gas phase $\mathrm{Hg}$ to Lakes St. Clair, Huron and Erie, the Hybrid Receptor-Deposition Model (Pirrone et al. 1994a; 1994b) developed to estimate the deposition flux of trace metals and semivolatile organic compounds (SOCs) to Lake Michigan was modified for $\mathrm{Hg}$.

\section{Results and Discussion}

This study was aimed at assessing the levels of atmospheric $\mathrm{Hg}$ in the urban area of Detroit and estimating the ambient concentration, dry deposition flux and the air-water gas exchange rate of Hg over Lakes St. Clair, Huron and Erie. To accomplish these objectives, 24-hour integrated samples were used in the HRD model to evaluate the distribution of ambient concentrations and deposition fluxes of $\mathrm{Hg}$ in the particle and gas phase over the lakes. Dry deposition fluxes were determined for $\mathrm{Hg}$ in the gas phase and in the fine and coarse fraction measured at the industrial/urban sites in April 1992 and March 1994, and for particulate Hg with a mass median diameter (MMD) corresponding to the $50 \%$ collection efficiency of each MOI stage (see Table I). Major details on the particle size distribution of $\mathrm{Hg}$ measured with MOI can be found in Keeler $e t$ al. (1994b).

Table I shows ambient concentrations of $\mathrm{Hg}$ in the particle and gas phase measured in Detroit during April 1992 and March 1994. In March 1994 the particulate $\mathrm{Hg}$ concentration in the fine fraction ranged from $12 \mathrm{pg} / \mathrm{m}^{3}$ to $190 \mathrm{pg} / \mathrm{m}^{3}$, which represents $86 \%$ of the total suspended particulate $\mathrm{Hg}$. This finding agrees very well with the MOI data (obtained as sum of the last four MOI stages) which show that $86 \%$ of the atmospheric $\mathrm{Hg}$ collected on glass fiber filters of the last four MOI stages was in the fine fraction. Particulate Hg concentrations measured in March 1994 were found to be lower than those measured at the same location in Detroit in April 1992. The particulate $\mathrm{Hg}$ concentration measured in April 1992 ranged from $57 \mathrm{pg} / \mathrm{m}^{3}$ to $1230 \mathrm{pg} / \mathrm{m}^{3}$ at Site- 5 and from $69 \mathrm{pg} / \mathrm{m}^{3}$ to $1086 \mathrm{pg} / \mathrm{m}^{3}$ at Site- 1 with arithmetic means of $297 \mathrm{pg} / \mathrm{m}^{3}$ at Site-5 and $342 \mathrm{pg} / \mathrm{m}^{3}$ at Site-1. Ambient concentrations of $\mathrm{Hg}$ in the gas phase during April 1992 ranged from $0.41 \mathrm{ng} / \mathrm{m}^{3}$ to $3.5 \mathrm{ng} / \mathrm{m}^{3}$ at Site- 5 and from $9.5 \mathrm{ng} / \mathrm{m}^{3}$ to over $70 \mathrm{ng} / \mathrm{m}^{3}$ at Site- 1 . The high concentrations found at Site-1 suggest the impact of a significant local source. However, the lower particulate Hg concentrations measured in Detroit during March 1994 were likely due to the prevailing west-northwesterly winds during this period.

In April 1992 the prevailing winds were from the south-southeast suggesting transport of atmospheric $\mathrm{Hg}$ emitted from the industrial area of Detroit which includes coal combustion plants (e.g., coke ovens, iron and steel plants), municipal solid waste plants and sewage sludge incineration plants (Pirrone et al., 1994). These source types account for a large fraction $(>45 \%)$ of anthropogenic emissions of $\mathrm{Hg}$ in the United States (EPA, 1993).

Changes in the ambient concentrations of particulate and gas phase $\mathrm{Hg}$ with distane from the sampling sites are shown in Figure 2 for the forward trajectories which started in Detroit and traversed Lake St. Clair and Lake Erie on 9 April 1992 and on 7 March 1994 (Figure 1). The calculated $\mathrm{Hg}$ concentrations along the over-water trajectories were obtained using the $\mathrm{Hg}$ concentrations and particle size distributions measured at the sampling sites (Site-1 and Site-5) as input values in the HRD model. 


\section{TABLE I}

Ambient concentrations of $\mathrm{Hg}$ measured at Site- 1 and Site- 5 in the fine and coarse fraction $\left(\mathrm{pg} / \mathrm{m}^{3}\right)$, in the gas phase $\left(\mathrm{ng} / \mathrm{m}^{3}\right)$, and on particles collected on each Micro-Orifice Impactor (MOI) stage $\left(\mathrm{pg} / \mathrm{m}^{3}\right)$. The mass median diameters $(\mu \mathrm{m})$ corresponding to a $50 \%$ collection efficiency of each MOI stage is given.

\begin{tabular}{lcccc}
\hline Particle Size & Sampling Period & Mass Median Diameter & Site - 1 & \multicolumn{1}{c}{ Site - 5 } \\
\hline Fine $(<2.5 \mathrm{~mm})$ & April 5-17, 1992 & 0.6 & 290 & 252 \\
Coarse $(>2.5 \mathrm{~mm})$ & ibid. & 5.0 & 51.3 & 44.5 \\
Gas phase & ibid. & & 48.8 & 3.4 \\
Fine $(<2.5 \mathrm{~mm})$ & March 1-18, 1994 & 0.6 & & 86 \\
Coarse $(>2.5 \mathrm{~mm})$ & ibid. & 5.0 & & 12 \\
Micr0-0rifice Impactor : & ibid. & & \\
Stage-1 & & 5.0 & 6 \\
Stage-2 & & 2.5 & 6 \\
Stage-3 & & 1.0 & \\
Stage-4 & & 0.6 & \\
Stage-5 & & 0.18 & 33 \\
\hline
\end{tabular}

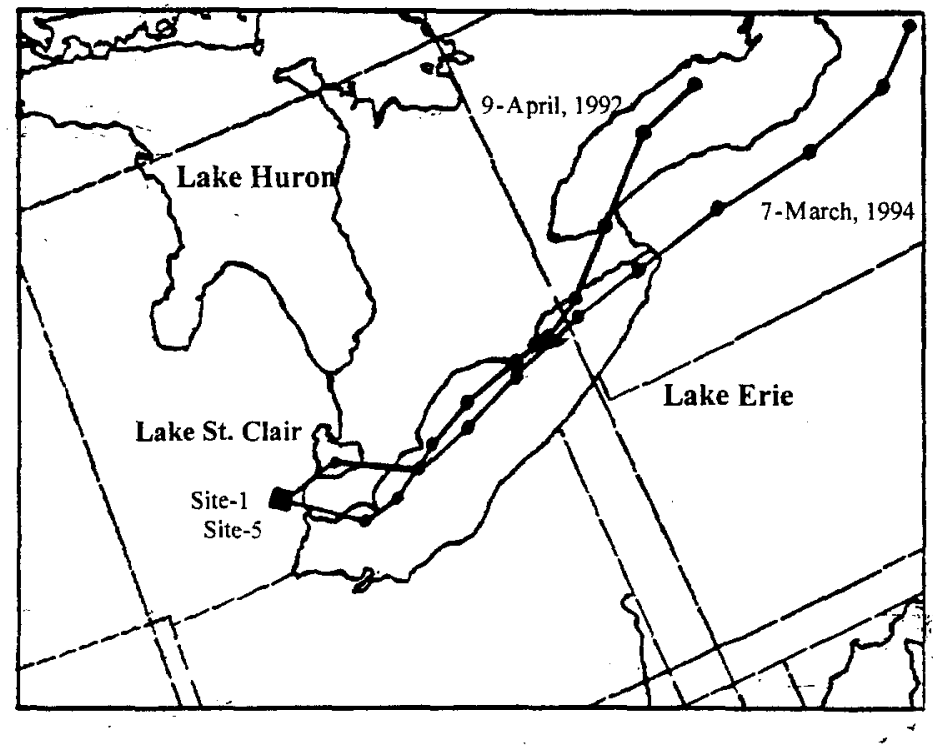

Fig. 1. Forward trajectories which started in Detroit and traversed Lake St. Clair and Lake Erie on 9 April 1992 and 7 March 1994. 
The concentrations of particulate $\mathrm{Hg}$ in the fine and coarse fraction (Figure 2b) decreased by a factor of 12 and 18, respectively, when the air mass moved from the sampling site to the lakes. The decrease in ambient concentration was mainly due to atmospheric dispersion during transport with deposition accounting for only 10 and $22 \%$ of the overall decrease in the $\mathrm{Hg}$ concentrations in the fine and coarse fractions, respectively. The gas phase $\mathrm{Hg}$ concentrations decreased along the over-water trajectory by a factor of 15 compared to that measured at the sampling sites on 9 April 1992. Figure 1-c shows the decrease in the ambient concentration along the over-water trajectories that traversed Lakes St. Clair and Erie on 7 March 199.7. The overall decrease in the ambient $\mathrm{Hg}$ concentrations are similar to those obtained for the fine and coarse fraction along the trajectory that traversed the lakes on 9 April 1992 (Figure 2b). However, the increase in the ambient concentration observed when the air mass was at a distance of $10-20 \mathrm{~km}$ from the sampling site (Figure 2c) was due to a decrease in the mixing layer depth (from $1080 \mathrm{~m}$ to $660 \mathrm{~m}$ ) occurring over the lake during transport. The $\mathrm{Hg}$ levels over the lakes reached the minimum value of $10-20 \mathrm{pg} / \mathrm{m}^{3}$ in the particle phase and $1.5-2 \mathrm{ng} / \mathrm{m}^{3}$ in the gas phase at a distance $>40 \mathrm{~km}$ from the sampling sites. These $\mathrm{Hg}$ levels are similar to the regional background levels observed in the Great Lakes Region (Keeler et al., 1994b; Burke et al., 1994).

Figure 3 shows the change in dry deposition flux of $\mathrm{Hg}$ in the particle and gas phase with distance from the sampling sites when the air masses moved from Detroit over Lake Erie on 9 April 1992 and 7 March 1994. The exchange rates of gas phase $\mathrm{Hg}$ at the air-water interface, F-1 and F-5 (Figure 3a), were calculated using the measured concentrations at sampling sites Site-1 and Site-5, respectively, and a total $\mathrm{Hg}$ concertration in the dissolved aqueous phase of $0.5 \mathrm{ng} / \mathrm{L}$ (Gill and Bruland, 1990). Since measurements were not available to estimate the spatial and temporal variations of the total $\mathrm{Hg}$ in the dissolved aqueous phase, $\mathrm{a}^{\mathrm{H}}{ }^{\mathrm{O}}$ concentration of 0.05 $\mathrm{ng} / \mathrm{L}$ was assumed constant throughout the lakes area. This value was used to evaluate the exchange rate of gas phase $\mathrm{Hg}$ at the air-water interface. The exchange rate of gas phase $\mathrm{Hg}$ increased up to a factor of 2 during transport. Similar changes were found in other critical parameters effecting the gas exchange at the air-water interface such as the overall air-water transfer coefficient, KoL, which ranged from 1.1 to $4 \mathrm{~cm} / \mathrm{h}$, Henry's law constant, $H$, which ranged from 120 to $175 . \mathrm{Pa} / \mathrm{m}^{3}$-mole, the temperăture at the air-water interface, $\mathrm{Ta}-\mathrm{w}$, which varied by $50 \%$ on average, the wind speed, Ws, which ranged from 2.3 to $0.8 \mathrm{~m} / \mathrm{h}$ and the mixing layer depth, $Z \mathrm{mix}_{\text {, }}$ which ranged from 1080 to $620 \mathrm{~m}$. The increase found in the Kol was associated with a decrease in the Zmix which led to an increase in the ambient concentrations along the overwater trajectory with higher exchange rates of the gas phase $\mathrm{Hg}$. However, it is likely that the airwater exchange rate is actually more variable than that found in this study since changes in the $\mathrm{Hg}^{\mathrm{O}}$ concentration in the lakes were not measured. The dry deposition flux of fine and coarse fraction $\mathrm{Hg}$ decreased 10 -fold along the over-water trajectory (Figure $3 b$ ). Similar variations were found in the deposition flux of particulate $\mathrm{Hg}$ obtained using the MOI data (Figure 3c). These changes ranged from 20 -fold for $\mathrm{Hg}$ associated with $0.18 \mu \mathrm{m}$ diameter particles (Stage- 5 of the $\mathrm{MOI}$ ) to 10 -fold for $\mathrm{Hg}$ associated with $5 \mu \mathrm{m}$ diameter particles (Stage-1 of the MOI). Variations in the dry deposition flux of particulate $\mathrm{Hg}$ are mainly due to changes in deposition velocity and ambient concentration along the trajectories traversing the lakes (Pirrone et al., 1994a). Figure 4 shows the volatilization rates from the lakes and/or deposition to the lakes for eaeh forward trajectory that traversed each lake during April 1992. The exchange rates of the gas phase $\mathrm{Hg}$ ranged from $0.8 \mathrm{ng} / \mathrm{m}^{2}-\mathrm{h}$ (deposition to the water surface) to $-0.5 \mathrm{ng} / \mathrm{m}^{2}-\mathrm{h}$ (volatilization from the water surface) when $\mathrm{Hg}$ concentrations measured at Site- 5 were used. When $\mathrm{Hg}$ concentrations measured at Site-1 are utilized, the HRD model estimates that only volatilization occures from the 

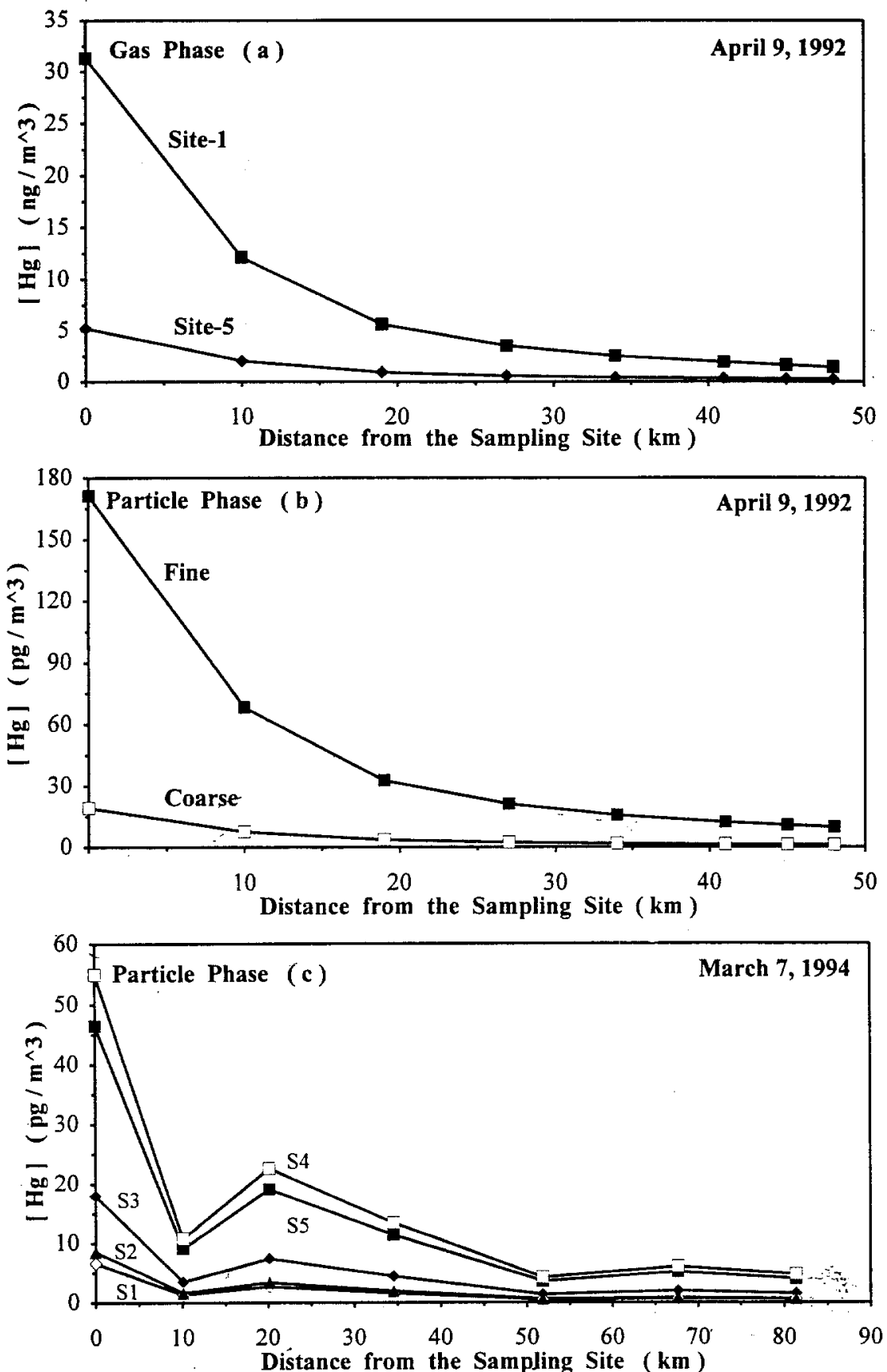

Fig. 2. Calculated $\mathrm{Hg}$ concentrations in the gas and particle phase along 24-hour forward trajectories traversing Lake St. Clair and Lake Erie on 9 April 1992 and on 7 March 1994 using the Hg concentrations measured at Site-1 and Site-5. 
lakes. These findings suggest that based on the assumption of a constant $\mathrm{Hg}^{\circ}$ concentration equal to $0.05 \mathrm{ng} / \mathrm{L}$ in the dissolved aqueous phase, the lakes are degassing $\mathrm{Hg}$ into the atmosphere.

The respective changes in dry deposition flux of particulate $\mathrm{Hg}$ in the fine and coarse fraction were 8-fold and 15-fold, respectively, when the concentrations measured at Site-1 were used, and 25 -fold and 30 -fold when the concentrations measured at Site-5 were used. The higher variations in the dry deposition flux of $\mathrm{Hg}$ over the lakes obtained using Site-5 data were likely due to larger variations in the activity of local emission sources located upwind of Site-5, since the effect of variations in the parameters controlling the transport of the air mass and particle deposition velocity over the water were similar for both sites.

The deposition flux of particulate $\mathrm{Hg}$, obtained as averages of those obtained along each forward trajectory using the MOI data, shows 6-fold variations for the MOI-Stage1, 7-fold for the MOI-Stage2, 16-fold for the MOI-Stage3, 15-fold for the MOI-Stage4 and 7-fold for the MOIStage5 (Figure 5). The higher variations in the dry deposition flux of $\mathrm{Hg}$ associated with particles with a $M M D=1 \mu \mathrm{m}$ are in good agreement with results obtained by Pirrone et al. (1994a) for trace metals associated with $1.3 \mu \mathrm{m}$ diameter particles.

Table II shows the estimated deposition fluxes of atmospheric $\mathrm{Hg}$ in the gas and particle phase using the measurements made at sites Site-1 and Site-5 in April 1992 and March 1994 as input values to the HRD model. Dry deposition fluxes of total particulate $\mathrm{Hg}$ (fine+coarse) obtained using the $\mathrm{Hg}$ concentrations measured in April 1992 at Site-1 were higher than those estimated using the $\mathrm{Hg}$ concentrations measured at Site-5. However, Lake Erie was more impacted by the urban plume generated in Detroit with dry deposition fluxes in the range of 112 to $125 \mathrm{pg} / \mathrm{m}^{2}$-h, followed by Lake St. Clair 67 to $109 \mathrm{pg} / \mathrm{m}^{2}-\mathrm{h}$ and Lake Huron 19 to $31 \mathrm{pg} / \mathrm{m}^{2}$ h. In March 1994 the dry deposition flux of particulate $\mathrm{Hg}$ (fine+coarse) was lower than that obtained during April 1992. However, Lake St. Clair is more impacted by the transport of air masses of urban origin with an average deposition flux of $57 \mathrm{pg} / \mathrm{m}^{2} \mathrm{~h}$, followed by Lake Erie 24 $\mathrm{pg} / \mathrm{m}^{2} \mathrm{-h}$ and Lake Huron $-5.2 \mathrm{pg} / \mathrm{m}^{2}-\mathrm{h}$. Hg volatilization rates from the lakes were predicted to range from -0.13 to $-0.36 \mathrm{ng} / \mathrm{m}^{2}-\mathrm{h}$ for Lake Erie and -0.21 to $-0.52 \mathrm{ng} / \mathrm{m}^{2}-\mathrm{h}$ for Lake Huron. Predicted $\mathrm{Hg}$ volatilization from Lake St. Clair was at a rate of $-0.5 \mathrm{ng} / \mathrm{m}^{2}-\mathrm{h}$ when $\mathrm{Hg}$ concentrations measured at Site- 5 were used, while deposition to the lake at a rate of $5.9 \mathrm{ng} / \mathrm{m}^{2}-\mathrm{h}$ was predicted when $\mathrm{Hg}$ concentrations measured at Site-1 were used. The volatilization rates obtained in this study were similar to those estimated by Vandal et al. (1991).

TABLE II

Dry deposition flux of $\mathrm{Hg}$ in the gas phase $\left(\mathrm{ng} / \mathrm{m}^{2}-\mathrm{h}\right)$, in the particle phase $\left(\mathrm{pg} / \mathrm{m}^{2}-\mathrm{h}\right)$ for each Micro-Orifice Impactor (MOI) stage, and in the fine and coarse fraction $\left(\mathrm{ng} / \mathrm{m}^{2}-\mathrm{h}\right.$ ) calculated for Lakes St. Clair, Huron and Erie during April 1992 and March 1994. Negative values imply volatilization of the gas phase $\mathrm{Hg}$ from the lake.

\begin{tabular}{|c|c|c|c|c|c|c|c|c|c|}
\hline & \multicolumn{3}{|c|}{ Lake St. Clair } & \multicolumn{3}{|c|}{ Lake Huron } & \multicolumn{3}{|c|}{ Lake Erie } \\
\hline & $\begin{array}{c}\text { Apr-1992 } \\
\text { Site-1 }\end{array}$ & $\begin{array}{c}\text { Apr-1992 } \\
\text { Site-5 }\end{array}$ & $\begin{array}{c}\text { Mar-1994 } \\
\text { Site-5 }\end{array}$ & $\begin{array}{c}\text { Apr-1992 } \\
\text { Site-1 }\end{array}$ & $\begin{array}{c}\text { Apr-1992 } \\
\text { Site-5 }\end{array}$ & $\begin{array}{c}\text { Mar-1994 } \\
\text { Site-5 }\end{array}$ & $\begin{array}{c}\text { Apr-1992 } \\
\text { Site-1 }\end{array}$ & $\begin{array}{l}\text { Apr-1992 } \\
\text { Site-5 }\end{array}$ & $\begin{array}{c}\text { Mar-1994 } \\
\text { Site-5 }\end{array}$ \\
\hline $\begin{array}{l}\text { Gas phase } \\
\text { MOI: }\end{array}$ & 5.9 & -0.5 & & -0.21 & -0.5 & & -0.36 & -0.13 & \\
\hline Stage-1 & & & 23.5 & & & 3.6 & & & 15.2 \\
\hline Stage-2 & & & 5.8 & & & 1 & & & 5.1 \\
\hline Stage -3 & & & 4.15 & & & 0.41 & & & 3.7 \\
\hline Stage -4 & & & 2.3 & & & 0.17 & & & 1.5 \\
\hline Stage-5 & & & 0.63 & & . & 0.02 & & & 0.4 \\
\hline Fine & 25 & 15.3 & 7.1 & 6.8 & 4.2 & 0.52 & 20.6 & $18.5^{-}$ & 5.1 \\
\hline Coarse & 84 & 51.4 & 50 & 24.2 & 15 & 4.7 & 104 & 93 & 19 \\
\hline
\end{tabular}



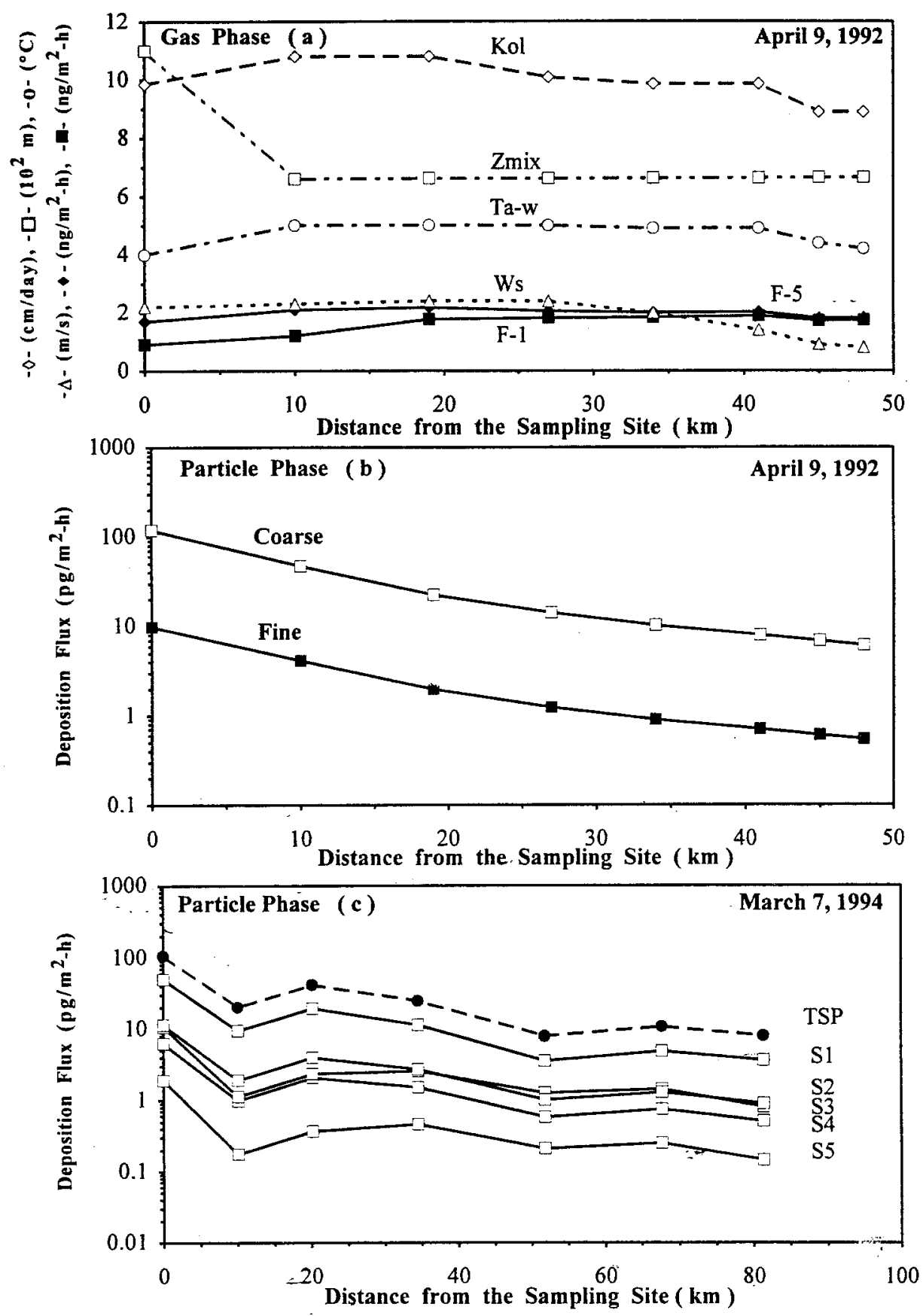

Fig. 3. Volatilizatiun rates of the gas phase $\mathrm{Hg}$ and dry deposition fluxes of the particulate $\mathrm{Hg}$ along the forward trajectories that traversed Lake St. Clair and Lake Erie on 9 April 1992 and on 7 March 1994. 

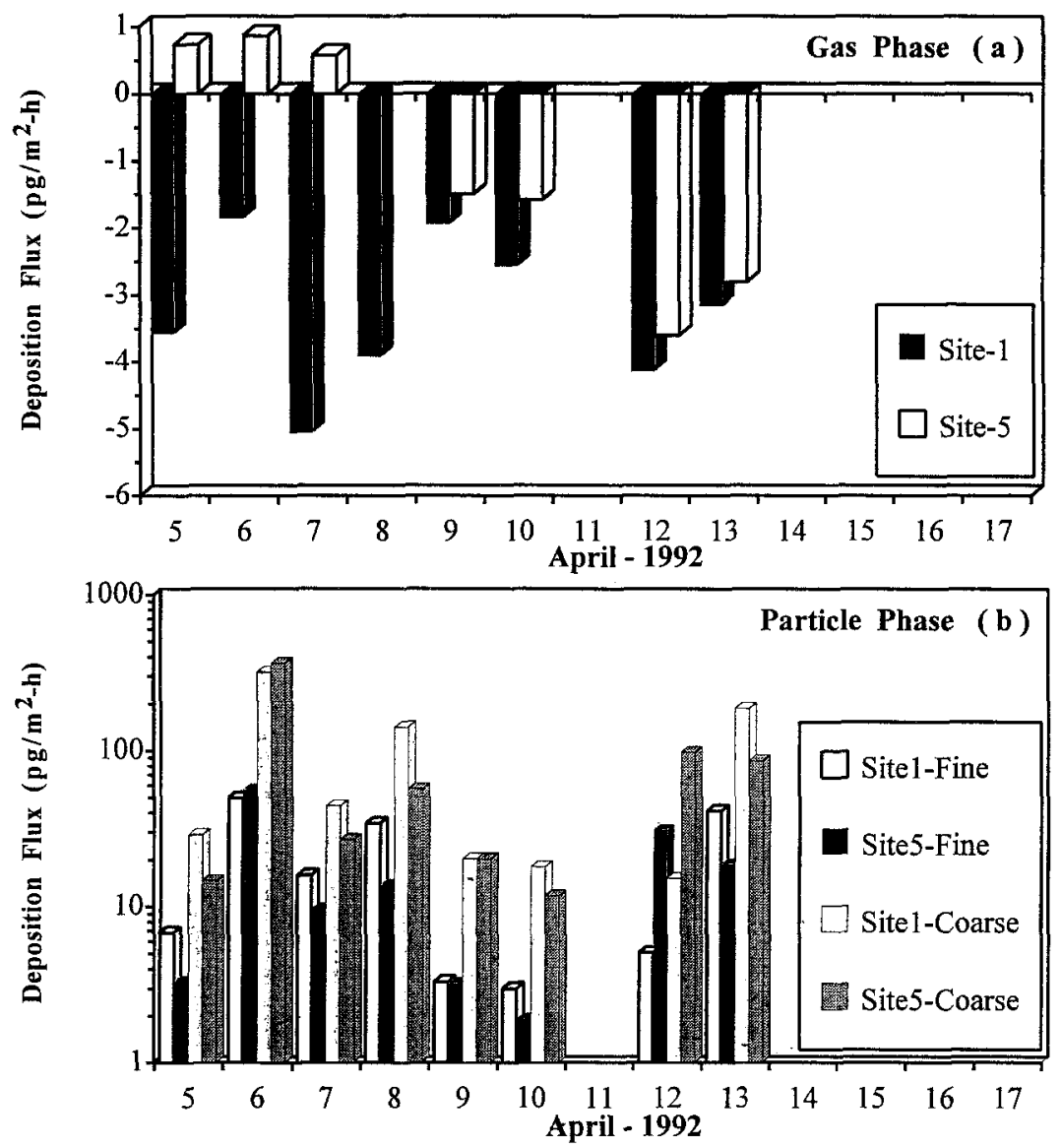

Fig. 4. Dry deposition fluxes of $\mathrm{Hg}$ in the gas and particle phase obtained as average of those calculated along each over-water trajectory traversing Lake St.Clair, Lake Huron and Lake Erie. Negative values imply volatilization of gas phase $\mathrm{Hg}$ from the lake.

\section{Summary and Conclusions}

Temporal and spatial variations of atmospheric concentrations and deposition fluxes of $\mathrm{Hg}$ associated with both the particle and gas phase over Lakes St. Clair, Erie and Huron were estimated using a hybrid receptor-deposition model (HRD). An evaluation of the variations in the particle deposition velocities and gas exchange rates of $\mathrm{Hg}$ during transport was performed. The overall variations in the deposition fluxes over the lakes ranged from 20 -fold for $0.18 \mu \mathrm{m}$ diameter particles to 10 -fold for $5 \mu \mathrm{m}$ diameter particles. The estimated exchange rates of the gas phase $\mathrm{Hg}$ were affected 'by the sampling site location and the fraction of $\mathrm{Hg}^{\mathrm{O}}$ in the total $\mathrm{Hg}$ dissolved in the aqueous phase. Therefore, gas phase $\mathrm{Hg}$ was predicted to volatilize from Lake Huron and Lake Erie at a rate of -0.21 to $-0.5 \mathrm{ng} / \mathrm{m}^{2}-\mathrm{h}$ and -0.13 to $-0.36 \mathrm{ng} / \mathrm{m}^{2}-\mathrm{h}$, respectively. The model predicted that Lake St. Clair was degassing $\mathrm{Hg}$ at a rate of $0.5 \mathrm{ng} / \mathrm{m}^{2}-\mathrm{h}$ when Site-5 data were used, and when the higher ambient concentrations measured at Site-1 were utilized gas phase $\mathrm{Hg}$ was deposited to Lake St. Clair at a rate of $5.9 \mathrm{ng} / \mathrm{m}^{2} \mathrm{~h}$. These results suggest that gas phase $\mathrm{Hg}$ can be deposited to the water surface (e.g., Lake St. Clair) when the air mass is near the emission sources, while it is re-emitted to the atmosphere at locations more distant. 


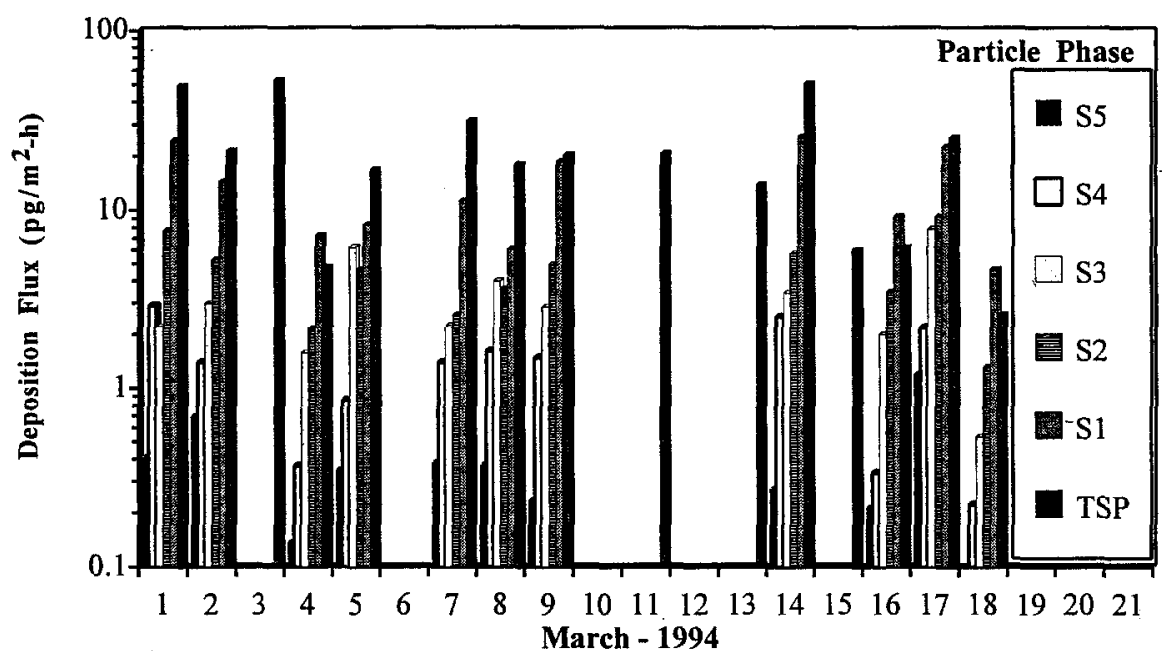

Fig. 5. Dry deposition fluxes of particulate Hg for each particle size range of the MOI stages, obtained as average of those calculated along each over-water trajectory that traversed Lakes St.Clair, Huron and Erie during March 1994.

\section{Acknowledgment}

The authors would like to thank all those of the UMAQL involved in sample collection and analysis who contributed greatly to the quality of the data.

\section{References}

Burke, J., Hoyer, M., Keeler, G.J. and Scherbatskoy, T.:1994, Water Air and Soil Pollut., in this volume.

EPA, Locating and Estimating Air Emissions from Sources of Mercury and Mercury Compounds, Midwest Research Institute, North Caroline, Interim Report, January 1993.

Fitzgerald, W.F., Gill, G.A.:1979, Anal. Chem.,51, 11: 1714-1720.

Gill, G.A. and Bruland, K.W.: 1990, Environ. Sci. Technol. 24, 1392-1397.

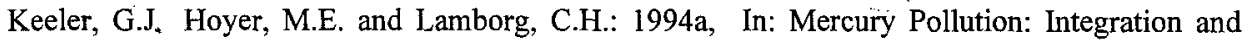
Synthesis, Watras, C.J. and Huckabee, W. (Eds), Lewis Publishers, Chelsea, MI.

Keeler, G.J., Glinsorn, G. and Pirrone, N.: 1994b, Water Air and Soil Pollut., in this wolume.

Lindqvist, O., Johansson, K., Aastrup, M., Anderson, A.:1991, Water Air Soil Pollut. 55, 7-17.

Meger, S.A.:1986, Water Air Soil Pollut. 30, 411-19.

Nater, E.A. and Grigal, D.F.:1992, Nature 358, 139-41.

Norton, S.A., Dillon, P.J., Douglas E.R., Mierle, G. and Kahl, J.S. in Acidic Precipitation, Vol.3, 73, Springer, Berlin (1990).

Pirrone, N., Keeler, G.J. and Holsen, T.M.: 1994a, submitted to Environ. Sci. Technol.

Pirrone, N., Keeler, G.J. and Holsen, T.M.: 1994b, submitted to Environ. Sci. Technol.

Pirrone, N., Keeler, G.J. and Warner, P.O.:1994, Sci. Tot. Environ, in press.

Rada, R.G., Wiener, J.G;, Winfrey, M.R. and Powell, D.E.:1989, Arch. Envir. Contam. Toxicol. $18,175-81$.

Slemer, F. and Langer, E.:1992, Nature 355, 434-37.

Swain, E.B., Engstrom, D.R., Brigham, M.E., Henning, T.A., Brezonik, P.L.:1992, Science 257, 784-87.

Vandal, G.M., Mason, R.P. and Fitzgerald, W.F.: 1991, Water Air and Soil Poll. 56, 791-803. 